\title{
Combining Ability Analysis for Yield and Attributing Traits in Field Pea (Pisum sativum L.)
}

\author{
Bhumika Yadav*, Abhinav Sao and Deepak Gauraha \\ Indira Gandhi Krishi Vishwavidalaya Raipur (CG), India \\ *Corresponding author
}

\section{A B S T R A C T}

\begin{tabular}{|l|}
\hline Key w o r d s \\
Combining ability, \\
General combiner, \\
Specific combiner \\
\hline Article Info \\
\hline Accepted: \\
15 May 2019 \\
Available Online: \\
10 June 2019 \\
\hline \hline
\end{tabular}

\begin{abstract}
In the present investigation 7 parents and $21 \mathrm{~F}_{1}$ hybrids of field pea were evaluated in a randomized complete block design in three replication to estimate combining ability of genotypes by using diallel fashion for the yield and yield attributing characters at instructional farm of Indira Gandhi Krishi Vishwavidyalaya, Raipur during the Rabi December 2017 to March 2018. Combining ability analysis indicated contribution of non additive gene effect playing an important role for most of the characters and the analysis of variance due to general combining ability (gca) and specific combining ability (sca) revealed highly significant for most of the characters. The parent Indira Matar-1 was recorded as the best general combiner for secondary branches per plant, seed per pod seed per plant and seed yield per plant. The crosses Aman x KPMR 400 was recorded as the best combiner for days to maturity, seed per plant, 100 seed weight, seed yield per plant and biological yield per plant.
\end{abstract}

\section{Introduction}

Legumes are critical harvests around the world, and they impactsly affect farming, condition, creature and human nourishment (Graham and Vance, 2003). Legumes can team up advantageously with trademark soilborne microorganisms called rhizobia, enabling it to fix environmental nitrogen, improve the physical state of the soil, and potentially ensure them against some parasitic pathogens (Chakraborty et al., 2003). Field pea (Pisum sativum L.) is one of the world's oldest domesticated crops cultivated before $10^{\text {th }}$ and $9^{\text {th }}$ millennia BC (Zohary et al., 2000). Pisum sativum comprise of both the wild species ( $P$. fulvum and P. eratius) and developed species ( $P$. abyssinicum) started from the Mediterranean locale, principally in the Middle East (Ellis et al., 2011).Field pea is rich in high quality protein and also good source of phosphorus, calcium and vitamins specifically vitamin A and D. Peas are highly nutritive having high percentage of protein $(6.2 \mathrm{~g} / 100 \mathrm{~g}$ of fresh weight) and carbohydrates $(16.9 \mathrm{~g} / 100 \mathrm{~g}$ of fresh weight) along with essential minerals, vitamins $\mathrm{A}, \mathrm{B}$ and $\mathrm{C}$ (Makasheva, 1983) and provide a major portion of the nutritive proteins to the poor masses, majority of which are vegetarian. As a result of static pulse production and repeated increase in population, the per capita 
availability of pulses has decline considerably. The per capita per day availability of pulses in 1951 was $60 \mathrm{~g}$ that dwindled down to a provisional level of 47.2 $\mathrm{g}$ in the year 2014. The per capita per year availability shows the same decreasing trend from $22.1 \mathrm{~kg}$ in 1951 to $17.2 \mathrm{~kg}$ in 2014. However the increase trend shows during 2017 both in per capita per day (52.9 g) and per capita per year $(19.3 \mathrm{~kg})$ respectively (Anonymous 2012). This can be improved through using various breeding methods among the population. Therefore, the aim of present investigation was on combing ability analysis of field pea for enhancing yield and its attributes.

\section{Materials and Methods}

The experimental material consisted of seven parents viz., Ambika, Indira Matar, Pant P250, Aman, IPFD 15-8, IGP 2018-1 and KPMR 400. These parents are crossed in diallel fashion to develop $21 \mathrm{~F}_{1}$ crosses during Rabi 2016-17. In subsequent year 7 parents and their $21 \mathrm{~F}_{1}$ 's were evaluated in a Randomized Block Design with 3 replication during Rabi 2016-17.Combining ability and gene for each phenotype was estimated for yield and its attributes following a procedure Jinks and Hayman (1954). The data were analyzed following model suggested by Griffing (1956) as well as Hayman (1954) for combining ability analysis.

\section{Results and Discussion}

"The GCA variance of parents and SCA variance of hybrids for the different characters are important basic criteria for the selection or hybridization programme. The variances due to general combining ability for different characters under study and their ratio are presented in Table 1." The analysis of variance due to general combining ability (GCA) revealed high for number of secondary branches per plant (10.69), no. of pod per plant (2.50), seed per plant (70.29), biological yield per plant (17.14). The SCA variance was found highest for Days to maturity (4.01), secondary branches per plant (30.15), pod per plant (17.45), seed per plant (639.07), 100 seed weight (2.06), seed yield per plant (12.54), harvest index (9.06), and dal recovery (3.04).

Genetic component of variance due to SCA was found highest for number of seeds per plant (639.07) followed by biological yield per plant (65.97), number of secondary branches per plant (30.15), number of pods per plant (17.45), seed yield per plant (12.45), days to maturity (4.01) and 100 seed weight (2.06).

Study of GCA and SCA variance revealed that variance due to SCA was more than the GCA variance in all studied characters except for days to $50 \%$ flowering, days to maturity, 100 seed weight and protein content, indicating the non-additive nature of gene action hence suggesting the, possibility of exploiting heterosis for these traits in field pea.

The comparative variances due to general combining ability and specific combining ability for different characters under study and their ratio presented in the Table 2 revealed that non additive genetic variances accomplished an important role in the expression of different traits, which indicated the predominance of non-additive gene action in the inheritance of above mentioned traits.

Study of GCA effects explained that, parent Indira Matar-1 was best combiner for secondary branches per plant, seed per pod, seed per plant, seed yield per plant and biological yield per plant. IPFD 15-8 was found best combiner for days to maturity, pod per plant, and seed per plant (Table 3 and 4). 
Table.1 ANOVA for combining ability analysis for seed yield, its components in pea

\begin{tabular}{|c|c|c|c|c|}
\hline \multirow[t]{4}{*}{ S. No. } & \multirow[t]{4}{*}{ Source of variation } & \multicolumn{3}{|c|}{ Mean Sum of Square (Hybrids) } \\
\hline & & GCA & SCA & Error \\
\hline & & \multicolumn{3}{|c|}{ Degree of Freedom } \\
\hline & & 6 & 21 & 54 \\
\hline 1 & Days to $50 \%$ flowering & $1.45 * *$ & $1.44 * *$ & 0.24 \\
\hline 2 & Days to maturity & $4.59 * *$ & $4.34 * *$ & 0.34 \\
\hline 3 & No. of primary branches per plant & 0.04 & $0.37 * *$ & 0.06 \\
\hline 4 & No. of secondary branches per plant & $98.52 * *$ & $32.47 * *$ & 2.32 \\
\hline 5 & No. of pods per plant & $35.81 *$ & $30.80 * *$ & 13.35 \\
\hline 6 & No. of seeds per pod & 0.15 & $0.30 * *$ & 0.07 \\
\hline 7 & No. of seeds plant & $769.85 * *$ & $776.34 * *$ & 137.28 \\
\hline 8 & 100 seed weight $(\mathrm{g})$ & 0.67 & $2.49 * *$ & 0.42 \\
\hline 9 & Seed yield per plant (g) & $12.67 * *$ & $13.76 * *$ & 1.23 \\
\hline 10 & Biological yield plant(g) & $170.79 * *$ & $82.51 * *$ & 16.54 \\
\hline 11 & Pod length $(\mathrm{cm})$ & 0.04 & $0.12 * *$ & 0.03 \\
\hline 12 & Harvest index $(\%)$ & $7.79 * *$ & $10.27 * *$ & 1.22 \\
\hline 13 & Swelling Capacity & $0.02 * *$ & $0.01 *$ & 0.01 \\
\hline 14 & Swelling Index (\%) & 0.00 & $0.001 * *$ & 0.001 \\
\hline 15 & Protein content $(\%)$ & $0.77 * *$ & $0.73 * *$ & 0.22 \\
\hline 16 & Dal Recovery (\%) & $2.04 * *$ & $3.28 * *$ & 0.24 \\
\hline
\end{tabular}

Table.2 Estimates of genetic components of variances for yield and its attributes in field.

\begin{tabular}{|c|c|c|c|c|}
\hline S. No. & Characters & $\sigma^{2}$ gca & $\sigma^{2}$ sca & $\sigma^{2}$ gca $/ \sigma^{2}$ sca \\
\hline 1. & Days to $50 \%$ flowering & 0.13 & 1.20 & 0.11 \\
\hline 2. & Days to maturity & 0.47 & 4.01 & 0.12 \\
\hline 3. & No. of primary branches per plant & 0.00 & 0.31 & -0.01 \\
\hline 4. & No. of secondary branches per plant & 10.69 & 30.15 & 0.35 \\
\hline 5. & No. of pods per plant & 2.50 & 17.45 & 0.14 \\
\hline 6. & No. of seeds per pod & 0.01 & 0.23 & 0.04 \\
\hline 7. & No. of seeds per plant & 70.29 & 639.07 & 0.11 \\
\hline 8. & 100 seed weight $(g)$ & 0.03 & 2.06 & 0.01 \\
\hline 9. & Seed yield per plant (g) & 1.27 & 12.54 & 0.10 \\
\hline 10. & Biological yield per plant(g) & 17.14 & 65.97 & 0.26 \\
\hline 11. & Pod length (cm) & 0.00 & 0.09 & 0.01 \\
\hline 12. & Harvest index (\%) & 0.73 & 9.06 & 0.08 \\
\hline 13. & Swelling Capacity & 0.00 & 0.01 & 0.31 \\
\hline 14. & Swelling Index (\%) & 0.00 & 0.00 & 0.34 \\
\hline 15. & Protein content $(\%)$ & 0.06 & 0.52 & 0.12 \\
\hline 16. & Dal Recovery (\%) & 0.20 & 3.04 & 0.07 \\
\hline
\end{tabular}


Table.3 Specific combining ability effects of hybrids for yield and its contributing traits in field pea

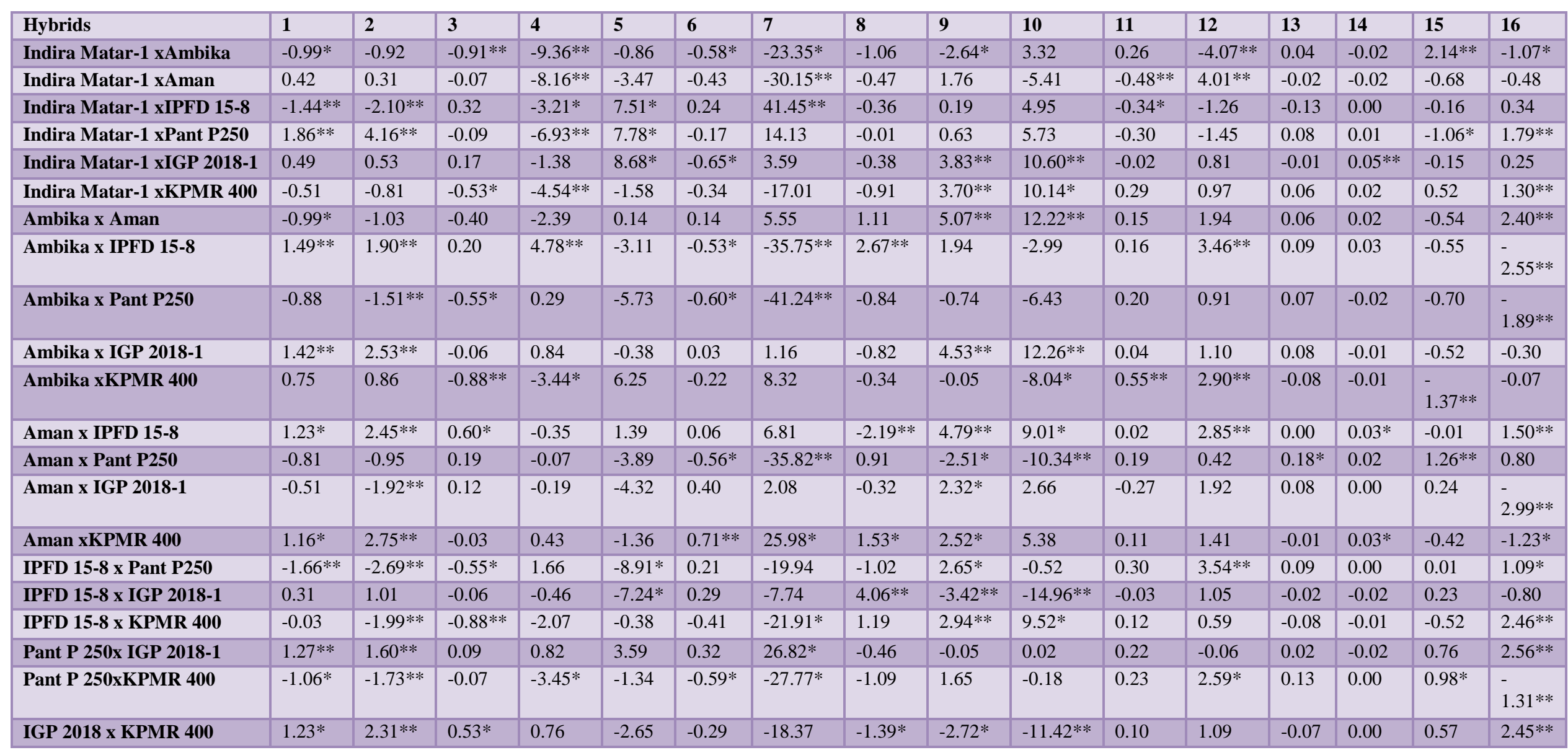
$*, * *$ differ significantly at 5 and 1 per cent level of probability, respectively.
1. Days to $50 \%$ flowering
7. No. of seeds per plant 1
2. Days to maturity
8. 100 seed weight $(\mathrm{g})$
2. Harvest index $(\%)$
3. No. of primary branches per plant
9. Seed yield per plant
10. Biological yield per plant
13. Swelling index $(\%)$
4. No. of secondary branches per plant
11. Pod length $(\mathrm{cm})$
14. Swelling capacity
15. Protein Content (\%)
5. No. of pods per plant
16. Dal Recovery

6. No. of seeds per pod 
Table.4 General combining ability effects of parents for yield and its contributing traits in field pea

\begin{tabular}{|c|c|c|c|c|c|c|c|c|c|c|c|c|c|c|c|c|}
\hline Parents & 1 & 2 & 3 & 4 & 5 & 6 & 7 & 8 & 9 & 10 & 11 & 12 & 13 & 14 & 15 & 16 \\
\hline \multicolumn{17}{|l|}{ Lines } \\
\hline $\begin{array}{l}\text { Indira Matar- } \\
1-1\end{array}$ & -0.19 & $-0.71 * *$ & -0.03 & $7.36^{* *}$ & 0.98 & $\begin{array}{l}0.23 \\
* *\end{array}$ & $9.27 *$ & -0.20 & $1.70 * *$ & $4.54 * *$ & 0.00 & 0.61 & -0.01 & 0.00 & -0.25 & 0.16 \\
\hline Ambika & $-0.45 * *$ & $-0.38 *$ & 0.10 & $-0.97 *$ & -0.74 & -0.01 & -1.37 & 0.04 & 0.37 & $4.23 * *$ & $-0.13 *$ & - & -0.01 & $\begin{array}{l}- \\
0.01 \\
* *\end{array}$ & 0.28 & $\begin{array}{l}- \\
0.73 \\
* *\end{array}$ \\
\hline Aman & -0.19 & $-0.60 * *$ & 0.02 & $-2.05 * *$ & 1.31 & 0.07 & $7.84^{*}$ & 0.09 & 0.23 & $3.52 * *$ & 0.04 & $\begin{array}{l}- \\
0.96 * \\
*\end{array}$ & $\begin{array}{l}0.07 * \\
*\end{array}$ & $\begin{array}{l}- \\
0.01 \\
* *\end{array}$ & 0.14 & $\begin{array}{l}0.74 \\
* *\end{array}$ \\
\hline IPFD 15-8 & $0.66 * *$ & $1.14^{* *}$ & -0.01 & $-1.11 *$ & $3.00 *$ & -0.04 & $9.00 *$ & 0.39 & $-1.23 * *$ & -1.90 & 0.07 & $\begin{array}{l}- \\
0.97 * \\
*\end{array}$ & 0.04 & $\begin{array}{l}0.01 \\
* *\end{array}$ & 0.14 & $\begin{array}{l}- \\
0.45 \\
* *\end{array}$ \\
\hline Pant P250 & -0.30 & -0.12 & -0.05 & -0.29 & $-2.71 *$ & 0.03 & -5.85 & -0.33 & $0.96 * *$ & -0.42 & 0.02 & $\begin{array}{l}1.41 * \\
*\end{array}$ & $\begin{array}{l}- \\
0.09 * \\
*\end{array}$ & 0.00 & -0.11 & 0.09 \\
\hline IGP 2018-1 & 0.40 & $0.84 * *$ & -0.09 & $-2.05 * *$ & -2.06 & -0.15 & $-15.38 * *$ & 0.27 & -0.36 & $-2.80 *$ & -0.01 & 0.48 & 0.02 & 0.01 & $\begin{array}{l}- \\
0.49 \\
* *\end{array}$ & -0.02 \\
\hline KPMR 400 & 0.07 & -0.16 & 0.06 & -0.89 & 0.20 & -0.13 & -3.50 & -0.26 & $-1.67 * *$ & $-7.16 * *$ & 0.01 & 0.24 & -0.01 & 0.01 & 0.29 & 0.21 \\
\hline
\end{tabular}
$*$, ** differ significantly at 5 and 1 per cent level of probability, respectively.
1. Days to $50 \%$ flowering
7. No. of seeds per plant
2. Days to maturity
8. 100 seed weight $(\mathrm{g})$
12. Harvest index $(\%)$
3. No. of primary branches per plant
9. Seed yield per plant
13. Swelling index $(\%)$
4. No. of secondary branches per plant
10. Biological yield per plant
14. Swelling capacity
5. No. of pods per plant
11. Pod length $(\mathrm{cm})$
15. Protein Content (\%)
16. Dal Recovery

6. No. of seeds per pod 
Graph.1 Showing that parent Indira Matar-1was best general combiner for seed yield per plant

\section{GCA Effects for Seed Yield/ Plant}

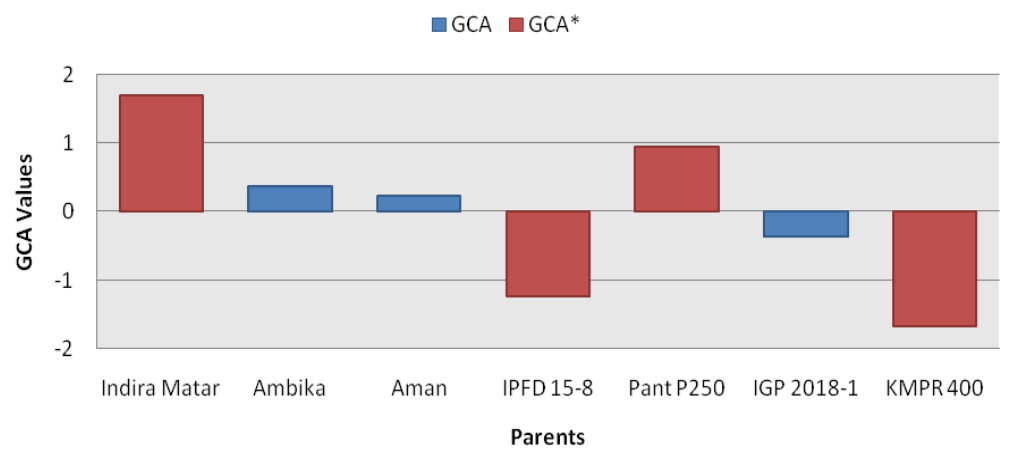

On the basis of SCA effects, the best cross combination was Ambika x IPFD 15-8 was observed as superior combiner for number of secondary branches per plant, 100 seed per plant and harvest index. The cross Indira Matar-1x IGP2018-1 for pod per plant, seed per plant, seed yield per plant, biological yield per plant. The cross Aman x KPMR 400 was suggested as desirable specific combiner for days to maturity, seed per plant, 100 seed weight, seed yield per plant and biological yield per plant. Comparative per se performance revealed that genotypes Indira Matar-1and IPFD 15-8 were higher yielder. Among the hybrid cross combinations Indira Matar-1x IGP 208-1, Indira Matar-1x KPMR 400, Ambika x Aman, Ambika x IGP 2018-1, Aman x IPFD15-8, Aman x KMPR400, and IPFD15-8 $x$ pant $P 250$ were best combiners for seed yield.

\section{References}

Anonymous, 2012. Package of Practices of Vegetable Crops P.A.U, Ludhiana, Punjab. Pp. 1.
Chakraborty, M., Haque, M.F., 2000. Genetic variability and component analysis in lentil (Lens culinaris Medik). Journal of Research Birsa Agricultural University, 12(2): 199-204.

Ellis, T.H.N. 2011. Pisum. In: Kole C. (ed.): Wild Crop Relatives: Genomic and Breeding Resources. Chapter 12, Springer-Verlag, Berlin-Heidelberg, 237-248.

Griffing, B. (1956). The concept of general and specific combining ability in selection to diallel crossing system. Aus. J. Biol. Sci., 9: 463-93.

Hayman, B.I. (1954a). The theory and analysis of diallel crosses. Genetics, 39: 789809.

Hayman, B.I. (1954b). The analysis of variance of diallel tables. Biometrics, 10: 235245

Makasheva, R.K. 1983. The pea. Oxonian Pvt. Ltd., New Delhi, India. pp. 78-107.

Zohary, D., Hopf, M. 2000. Domestication of Plants in the Old World. 3 edition. Oxford University Press: p.316.

\section{How to cite this article:}

Bhumika Yadav, Abhinav Sao and Deepak Gauraha. 2019. Combining Ability Analysis for Yield and Attributing Traits in Field Pea (Pisum sativum L.). Int.J.Curr.Microbiol.App.Sci. 8(06): 1976-1981. doi: https://doi.org/10.20546/ijcmas.2019.806.235 